(c) American Dairy Science Association, 2005.

\title{
Fecal Prevalence and Diversity of Salmonella Species in Lactating Dairy Cattle in Four States*
}

\author{
T. R. Callaway, ${ }^{1}$ J. E. Keen, ${ }^{2}$ T. S. Edrington, ${ }^{1}$ L. H. Baumgard, ${ }^{3}$ L. Spicer, ${ }^{4,5}$ \\ E. S. Fonda, ${ }^{4}$ K. E. Griswold, ${ }^{6}+$ T. R. Overton, ${ }^{7}$ M. E. VanAmburgh, ${ }^{7}$ \\ R. C. Anderson, ${ }^{1}$ K. J. Genovese, ${ }^{1}$ T. L. Poole, ${ }^{1}$ \\ R. B. Harvey, ${ }^{1}$ and D. J. Nisbet ${ }^{1}$ \\ ${ }^{1}$ Food and Feed Safety Research Unit, USDA/ARS, College Station, TX 77845 \\ ${ }^{2}$ Meat Animal Research Center, USDA/ARS, Clay Center, NE 68933 \\ ${ }^{3}$ Department of Animal Sciences, University of Arizona, Tucson 85721 \\ ${ }^{4}$ Department of Animal and Veterinary Sciences, California State Polytechnic University, Pomona 91765 \\ ${ }^{5}$ Nutri-Management, Inc., Claremont, CA 91711 \\ ${ }^{6}$ Department of Animal Science, Food, and Nutrition, Southern Illinois University, Carbondale 62901 \\ ${ }^{7}$ Department of Animal Science, Cornell University, Ithaca, NY 14853
}

\begin{abstract}
Salmonella is one of the most serious foodborne pathogenic bacteria in the United States, causing an estimated 1.3 million human illnesses each year. Dairy cows can be reservoirs of foodborne pathogenic bacteria, including Salmonella spp.; it is estimated that from 27 to $31 \%$ of dairy herds across the United States are colonized by Salmonella. The present study was designed to examine the occurrence of Salmonella spp. on dairies and to examine the serotypic diversity of Salmonella isolates on sampled dairies from across the United States. Fecal samples ( $\mathrm{n}=60$ per dairy) were collected from 4 dairies in each of 4 states for a total of 960 fecal samples representing a total population of 13,200 dairy cattle. In the present study, 93 of 960 samples $(9.96 \%)$ collected were culture-positive for Salmonella enterica. At least one Salmonella fecal-shedding cow was found in 9 of the 16 herds (56\%) and the within-herd prevalence varied in our study from $0 \%$ in 7 herds to a maximum of $37 \%$ in 2 herds, with a mean prevalence among Salmonella-positive herds of $17 \%$. Seventeen different serotypes were isolated, representing 7 different Salmonella serogroups. There were 2 or more different serogroups and serotypes present on 7 of the 9 Salmonella-positive farms. Serotypes Montevideo and Muenster were the most frequent and widespread.
\end{abstract}

Received February 7, 2005.

Accepted June 16, 2005.

Corresponding author: Todd R. Callaway; e-mail: callaway@ffsru. tamu.edu.

* Proprietary or brand names are necessary to report factually on available data; however, the USDA neither guarantees nor warrants the standard of the product, and the use of the name by the USDA implies no approval of the product, and exclusion of others that may be suitable.

$\dagger$ Present address: Penn State Cooperative Extension Service, Lancaster, PA 17601.
From our data, it appears that subclinical colonization with Salmonella enterica is relatively common on dairy farms and is represented by diverse serotypes on US dairy farms.

(Key words: Salmonella, food safety, fecal prevalence)

Abbreviation key: $\mathbf{C I}=$ confidence interval, NAHMS $=$ National Animal Health Monitoring System.

\section{INTRODUCTION}

One of the most serious foodborne pathogenic bacteria in the United States is Salmonella enterica (Mead et al., 1999). Human salmonellosis occurs in an estimated 1.3 million people, causes $>500$ deaths, and is estimated to cost the US economy more than $\$ 2.4$ billion each year (Mead et al., 1999; ERS/USDA, 2001). Salmonella spp. are estimated to cause more than $30 \%$ of all bacterial foodborne deaths (Mead et al., 1999). Many of these human illnesses can be linked to the consumption of bacterially contaminated ground beef, milk, or other dairy products (Holmberg et al., 1984; Hedberg et al., 1992).

Although Salmonella can cause illness in adult cattle, bovine salmonellosis is predominantly seen in young calves. Salmonella species have been isolated from the feces of healthy dairy cattle, where it may exist as a normal member of the gastrointestinal population, or as a transient member of the gastrointestinal microbial population (Roy et al., 2001; Wells et al., 2001; Edrington et al., 2004a). The most recently reported national dairy surveys [USDA National Animal Health Monitoring System (NAHMS) Dairy 1996 and 2002] indicated that 27 to $31 \%$ of US dairy herds contained cows that shed Salmonella (Wells et al., 2001; USDA/APHIS, 2003a). 
Salmonella enterica is a diverse bacterial species comprised of over 2500 serotypes (Popoff et al., 2004). In the USDA NAHMS (1996) survey, 25 different Salmonella serotypes were isolated from lactating dairy cows on-farm, and another 24 serotypes were isolated from dairy cows being culled from the herd (Wells et al., 2001). The present study was designed to provide an on-farm view of the prevalence of Salmonella spp. shedding by healthy lactating dairy cows at a single time point, and to determine the serotypic diversity of Salmonella isolates from cooperating dairies across the United States.

\section{MATERIALS AND METHODS}

\section{Study Design and Dairy Participation}

Fecal samples ( $\mathrm{n}=60$ per farm) were collected from 4 dairies per state for a total of $n=240$ fecal samples/ state. Participating dairy farms were a convenience sample of typical commercial dairies that had a working relationship with our collaborating in-state researchers. Farm identity was blinded from the researchers to ensure study participation and confidentiality. Samples were collected from dairies in Arizona, California, Illinois, and New York ( $\mathrm{n}=4$ states; total $\mathrm{n}=960$ fecal samples). States and farms were chosen to represent a spectrum of dairy operations and conditions (environmental and managerial) across the United States, and samples represented 13,200 adult lactating dairy cattle. Samples were collected randomly from lactating dairy cows as they entered the milking parlor. All samples were collected between June 15 and September 24, 2002 .

\section{Fecal Sample Collection}

Fresh fecal samples ( $\mathrm{n}=60$ per farm) were collected directly from healthy lactating dairy cows by rectal grab. Samples were collected using a new palpation sleeve for each sample. Sleeves were inverted upon collection, and samples were individually bagged in sealed plastic bags immediately after collection and kept on ice for $24 \mathrm{~h}$ during transport.

\section{Salmonella spp. Enrichments}

For qualitative enrichment of Salmonella, $3 \mathrm{~g}$ of feces was added to tubes containing $27 \mathrm{~mL}$ of tetrathionate broth (Difco Laboratories, Sparks, MD) and incubated at $37^{\circ} \mathrm{C}$ for $24 \mathrm{~h}$ (Difco Laboratories, 1998). After this incubation, $200 \mu \mathrm{L}$ of the tetrathionate enrichment were added to $5 \mathrm{~mL}$ of Rappaport-Vassiliadis R10 broth (Difco Laboratories) and incubated an additional $24 \mathrm{~h}$ at $42^{\circ} \mathrm{C}$ before being streak-plated onto brilliant green agar (Difco Laboratories) supplemented with novobiocin $(25 \mu \mathrm{g} / \mathrm{mL}$; Sigma Chemical Co., St. Louis, MO). The $\mathrm{BGA}_{\text {Nov }}$ plates were incubated for $24 \mathrm{~h}$ at $37^{\circ} \mathrm{C}$; colonies that exhibited typical Salmonella morphology were individually picked for further physiological characterization. Picked putative Salmonella colonies were inoculated onto triple sugar iron and lysine iron agar slants (Difco Laboratories). Each slant was incubated at $35^{\circ} \mathrm{C}$ for $24 \mathrm{~h}$. Putative Salmonella-positive samples were initially confirmed by slide agglutination using SM-O antiserum poly A-I and Vi, and group C1 factors (Difco Laboratories). Putative Salmonella isolates were stored in glycerol and tryptic soy broth at $-80^{\circ} \mathrm{C}$ until confirmatory serotyping was performed by the National Veterinary Services Laboratory in Ames, IA. It is important to note that the limit of detection for this enrichment methodology is approximately $1 \mathrm{cfu} / \mathrm{g}$ of feces; therefore, a negative result does not necessarily indicate the animal is negative, merely that the Salmonella population is present at less than $1 \mathrm{cfu} / \mathrm{g}$ of feces.

\section{Statistical Analyses}

Point prevalence of Salmonella shedding in each of the 16 sampled dairy herds was calculated individually by dividing the number of Salmonella culture-positive fecal samples by the total of samples collected per herd $(\mathrm{n}=60)$. The $95 \%$ exact binomial confidence intervals (CI) around each point estimate were calculated using Epi Info 6.0 (Centers for Disease Control, Atlanta, GA). Because the 60 fecal samples collected per herd represented a relatively large proportion (from $<5$ to $40 \%$ ) of each dairy population (the specific herd lactating cow population size), the finite population correction factor was applied to adjust the exact binomial 95\% CI.

Overall dairy cattle Salmonella prevalence with exact binomial $95 \%$ CI were calculated by pooling Salmonella results across all 16 herds. To further refine this Salmonella fecal shedding estimate, a populationweighted, cluster-adjusted estimate of prevalence was made using clusDATA, a software package designed for prevalence estimation under cluster sampling (http:// city.vetmed.fu-berlin.de/ mgreiner/clusDATA/ clusdata.htm; Greiner, 1997). Population weighting adjusted for variable milking population size, whereas cluster adjustment accounted for the fact that data were collected from herds (i.e., in clusters), and not from randomly selected, individual, statistically independent cattle.

Simpson's diversity index (D) was calculated across all 16 herds using the serotype and serogroup information for each of the Salmonella isolates (Hunter and Gaston, 1988; Grundmann et al., 2001). Simpson's D is an index, ranging from 0 to 1 , where higher values 
represent higher strain diversity. In this case, Simpson's D was the probability that any 2 randomly selected Salmonella isolated from US dairy cattle belong to different Salmonella serotypes or serogroups.

\section{RESULTS AND DISCUSSION}

Humans can be infected with Salmonella from animal sources by many routes (Holmberg et al., 1984). Improper milk pasteurization can lead to the inclusion of Salmonella in milk or dairy products, which can cause human illness, spread across many states (Hedberg et al., 1992). Approximately $50 \%$ of all ground beef in the United States is produced from culled dairy cows, and Salmonella can be transmitted to humans through improperly cooked ground beef (Mead et al., 1999). Consuming contaminated water and direct animal or fecal contact can result in human salmonellosis outbreaks (Pritchard et al., 2000; Enriquez et al., 2001). Because Salmonella can be spread from dairy cows via many routes, knowing the prevalence of Salmonella on dairy farms is crucial to devising strategies to interrupt pathogen transmission and recolonization cycles.

The Salmonella prevalence level in milking dairy cows was reported in the 1996 USDA NAHMS Dairy survey to be $5.4 \%$ (Wells et al., 2001); in the 2002 NAHMS dairy survey, the prevalence was found to be 7.3\% (USDA/APHIS, 2003a). In the present study, 93 of 960 samples $(9.96 \%)$ collected from a total population of 13,200 dairy cattle were culture-positive for Salmonella enterica (Table 1). Salmonella fecal prevalence in the present study was used to calculate an exact binomial 95\% CI with and without finite population correction. As expected, the finite population correction narrowed the 95\% CI compared with the uncorrected estimates. Because this study represented prevalence estimation under cluster sampling, it was desirable to adjust the point prevalence and 95\% CI for cluster effects. In general, cluster sampling will inflate the variance and widen the CI, and this, in fact, is what occurred. The unadjusted naive Salmonella prevalence estimate was $9.69 \%(7.89,11.7495 \%$ CI). The population-weighted, cluster-adjusted Salmonella prevalence was $9.07 \%(2.96,16.4195 \% \mathrm{CI})$.

At least one Salmonella fecal-shedding cow was found in 9 of the 16 herds (56\%) in our study, compared with 27.5 and $31 \%$ in the 1996 and 2002 NAHMS dairy surveys, respectively. The within-herd prevalence varied in our study from $0 \%$ in 7 herds, to a maximum of $37 \%$ in 2 herds, with an average among Salmonellapositive herds of $17 \%$ prevalence. The differences between our estimates and the NAHMS estimates are possibly due to the smaller relative sample size of our study compared with the much larger and comprehen- sive NAHMS 2002 Dairy survey. However, seasonality of fecal shedding may also have played a role; the NAHMS studies were conducted in February through July (1996), and March through September (2002), and our samples were collected from June through September, which is when fecal shedding appears to be at its highest (USDA/APHIS, 2001; Huston et al., 2002). An additional factor underlying potential differences between our results and those from the NAHMS dairy surveys is that the dairies in the present study tended to come from the western United States where herd sizes are larger (Table 1). Researchers have shown that as herd size increased, fecal shedding of Salmonella increased (Warnick et al., 2003); therefore, our results may contain a size-based bias by representing 2 large herd size states.

In the present study, 17 different serotypes were isolated representing 7 different serotype groups (serogroups) comprising the 93 Salmonella isolates (Table 1 and 2). There were 2 or more different serogroups and serotypes present on 7 of the 9 Salmonella-positive farms. Serogroup $\mathrm{C}_{1}$ in general, and $\mathrm{C}_{1}$ serotypes Montevideo and E1 Muenster were the most frequent and widespread, with 33 and 21 isolates from 6 and 4 dairies, respectively. Simpson's D for serotypes was 0.811 $(0.712,0.91195 \% \mathrm{CI})$ and Simpson's D for serogroups was $0.607(0.422,0.79195 \% \mathrm{CI})$, indicating that Salmonella serogroups, and especially serotypes, were very diverse across participating US dairy cattle farms.

In a study that examined the prevalence of Salmonella in healthy lactating dairy cows in New Mexico, a wide diversity of serotypes was also found (Edrington et al., 2004a). In that study, Mbandaka, Montevideo, and Kentucky were most prevalent, but Muenster was not represented (Edrington et al., 2004a). In another 2-yr study, the Montevideo serotype accounted for $27 \%$ of all dairy isolates from New Mexico and Texas, and Mbandaka, Senftenberg, and Newport comprised 15, 11 , and $7 \%$ of isolates, respectively (Edrington et al., 2004b). In the 1996 USDA NAHMS dairy survey, the most common serotypes were Montevideo, Cerro, Kentucky, Menhaden, Anatum, and Meleagridis (Wells et al., 2001), but in the 2002 NAHMS dairy survey, the predominant serotypes were Meleagridis, Montevideo, Typhimurium, Kentucky, and Agona (USDA/APHIS, 2003a). Surveys have also isolated Salmonella spp. from dairy bulk milk tanks (Jayarao and Henning, 2001; USDA/APHIS, 2003b), and the most common bulk tank serotypes across the United States were Montevideo, Newport, Muenster, Meleagridis, and Cerro (USDA/APHIS, 2003b).

It is important to note that all samples from the present study were collected from lactating dairy cattle in the active milking group on each farm. None of the 
Serogroup

กั

\begin{tabular}{|c|c|c|c|c|c|c|c|c|c|c|c|c|c|c|c|c|c|c|c|c|}
\hline \multirow[b]{3}{*}{ State } & \multirow[b]{3}{*}{ Farm } & \multirow{3}{*}{$\begin{array}{l}\text { Herd } \\
\text { size, }{ }^{1} \\
\text { no. }\end{array}$} & \multirow[b]{3}{*}{ Positive $^{2}$} & \multirow{2}{*}{\multicolumn{2}{|c|}{ B }} & \multicolumn{6}{|c|}{$C_{1}$} & \multirow{3}{*}{ 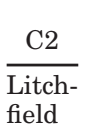 } & \multirow{3}{*}{$\frac{\text { C3 }}{\begin{array}{l}\text { Ken- } \\
\text { tucky }\end{array}}$} & \multirow{2}{*}{\multicolumn{4}{|c|}{$\mathrm{E} 1$}} & \multirow{2}{*}{\multicolumn{3}{|c|}{ E2 }} \\
\hline & & & & & & \multirow[b]{2}{*}{$\begin{array}{l}\text { Chole- } \\
\text { rasuis }\end{array}$} & \multirow[b]{2}{*}{ Lille } & \multirow[b]{2}{*}{$\begin{array}{l}\text { Mban- } \\
\text { danka }\end{array}$} & \multirow[b]{2}{*}{$\begin{array}{l}\text { Monte- } \\
\text { video }\end{array}$} & \multirow[b]{2}{*}{$\begin{array}{l}\text { Thomp- } \\
\text { son }\end{array}$} & \multirow{2}{*}{$\begin{array}{l}6,7: 1-5 \\
\text { mono- } \\
\text { phasic }\end{array}$} & & & & & & & & & \\
\hline & & & & Agona & $\begin{array}{l}\text { Typhi- } \\
\text { murium }\end{array}$ & & & & & & & & & $\begin{array}{l}\text { Ana- } \\
\text { tum }\end{array}$ & Give & $\begin{array}{l}\text { Muen- } \\
\text { ster }\end{array}$ & $\begin{array}{l}\text { Melea- } \\
\text { gridis }\end{array}$ & $3,15: \mathrm{e}$ & \multicolumn{2}{|l|}{ Hav- } \\
\hline \multirow[t]{4}{*}{$\mathrm{AZ}$} & A & 2000 & 1 & 0 & 0 & 0 & 0 & 0 & 0 & 0 & 0 & 0 & 0 & 0 & 0 & 0 & 1 & 0 & 0 & 0 \\
\hline & B & 800 & 6 & 0 & 0 & 0 & 0 & 1 & 1 & 0 & 0 & 0 & 0 & 1 & 0 & 0 & 0 & 0 & 1 & 2 \\
\hline & $\mathrm{C}$ & 1000 & 0 & 0 & 0 & 0 & 0 & 0 & 0 & 0 & 0 & 0 & 0 & 0 & 0 & 0 & 0 & 0 & 0 & 0 \\
\hline & D & 1000 & 0 & 0 & 0 & 0 & 0 & 0 & 0 & 0 & 0 & 0 & 0 & 0 & 0 & 0 & 0 & 0 & 0 & 0 \\
\hline \multirow[t]{4}{*}{ CA } & A & 1200 & 20 & 0 & 0 & 0 & 0 & 0 & 0 & 0 & 0 & 0 & 1 & 0 & 1 & 15 & 2 & 1 & 0 & 0 \\
\hline & B & 1000 & 10 & 0 & 2 & 0 & 0 & 2 & 4 & 0 & 0 & 0 & 0 & 0 & 0 & 4 & 0 & 0 & 0 & 0 \\
\hline & $\mathrm{C}$ & 1700 & 4 & 0 & 0 & 0 & 0 & 0 & 1 & 0 & 0 & 0 & 0 & 0 & 0 & 1 & 0 & 0 & 0 & 0 \\
\hline & D & 900 & 1 & 0 & 0 & 0 & 0 & 0 & 0 & 0 & 0 & 0 & 1 & 0 & 0 & 0 & 0 & 0 & 0 & 0 \\
\hline \multirow[t]{4}{*}{ IL } & A & 300 & 22 & 0 & 4 & 0 & 0 & 0 & 18 & 0 & 0 & 0 & 0 & 0 & 0 & 0 & 0 & 0 & 0 & 0 \\
\hline & B & 600 & 22 & 1 & 0 & 1 & 0 & 0 & 5 & 9 & 4 & 1 & 0 & 0 & 0 & 1 & 0 & 0 & 0 & 0 \\
\hline & $\mathrm{C}$ & 500 & 7 & 1 & 0 & 0 & 2 & 0 & 4 & 0 & 0 & 0 & 0 & 0 & 0 & 0 & 0 & 0 & 0 & 0 \\
\hline & D & 900 & 0 & 0 & 0 & 0 & 0 & 0 & 0 & 0 & 0 & 0 & 0 & 0 & 0 & 0 & 0 & 0 & 0 & 0 \\
\hline \multirow[t]{4}{*}{ NY } & A & 750 & 0 & 0 & 0 & 0 & 0 & 0 & 0 & 0 & 0 & 0 & 0 & 0 & 0 & 0 & 0 & 0 & 0 & 0 \\
\hline & B & 200 & 0 & 0 & 0 & 0 & 0 & 0 & 0 & 0 & 0 & 0 & 0 & 0 & 0 & 0 & 0 & 0 & 0 & 0 \\
\hline & $\mathrm{C}$ & 150 & 0 & 0 & 0 & 0 & 0 & 0 & 0 & 0 & 0 & 0 & 0 & 0 & 0 & 0 & 0 & 0 & 0 & 0 \\
\hline & $\mathrm{D}$ & 200 & 0 & 0 & 0 & 0 & 0 & 0 & 0 & 0 & 0 & 0 & 0 & 0 & 0 & 0 & 0 & 0 & 0 & 0 \\
\hline Total & 16 & 13,200 & 93 & 2 & 6 & 1 & 2 & 3 & 33 & 9 & 4 & 1 & 2 & 1 & 1 & 21 & 3 & 1 & 1 & 2 \\
\hline Number & of farm & $s$ with eac & h serotype & 2 & 2 & 1 & 1 & 2 & 6 & 1 & 1 & 1 & 2 & 1 & 1 & 4 & 2 & 1 & 1 & 1 \\
\hline \multicolumn{4}{|c|}{ Number of farms with each serotype } & \multicolumn{2}{|c|}{4} & \multicolumn{6}{|c|}{6} & 1 & 2 & & & 6 & & 1 & & \\
\hline
\end{tabular}

${ }^{1}$ Herd size $=$

${ }^{2}$ Positive $=$ Salmonella positive. 
Table 2. Salmonella enterica prevalence analysis by dairy cattle herd.

\begin{tabular}{|c|c|c|c|c|c|c|c|}
\hline State & Farm & $\begin{array}{l}\text { Unique } \\
\text { serotypes, } \\
\text { no. }\end{array}$ & $\begin{array}{l}\text { Unique } \\
\text { serogroups, } \\
\text { no. }\end{array}$ & $\begin{array}{l}\text { Total } \\
\text { no. of } \\
\text { isolates }\end{array}$ & $\begin{array}{l}\text { Salmonella } \\
\text { prevalence }\end{array}$ & $\begin{array}{l}\text { Exact } \\
\text { binomial } \\
95 \% \text { CI }\end{array}$ & $\begin{array}{l}\text { Exact } \\
\text { binomial } \\
95 \% \text { CI } \\
\text { with FPC }{ }^{1}\end{array}$ \\
\hline \multirow[t]{4}{*}{$\mathrm{AZ}$} & A & 1 & 1 & 1 & 0.017 & $0.000-0.089$ & $0.001-0.088$ \\
\hline & B & 5 & 3 & 6 & 0.1 & $0.038-0.205$ & $0.040-0.201$ \\
\hline & $\mathrm{C}$ & 0 & 0 & 0 & 0 & $0.000-0.060$ & $0.000-0.058$ \\
\hline & D & 0 & 0 & 0 & 0 & $0.000-0.060$ & $0.000-0.058$ \\
\hline \multirow[t]{4}{*}{$\mathrm{CA}$} & A & 5 & 3 & 20 & 0.333 & $0.217-0.467$ & $0.220-0.464$ \\
\hline & B & 3 & 2 & 10 & 0.167 & $0.083-0.285$ & $0.085-0.282$ \\
\hline & $\mathrm{C}$ & 3 & 3 & 4 & 0.067 & $0.018-0.162$ & $0.019-0.160$ \\
\hline & $\mathrm{D}$ & 1 & 1 & 1 & 0 & $0.000-0.089$ & $0.001-0.087$ \\
\hline \multirow[t]{4}{*}{ IL } & A & 2 & 2 & 22 & 0.367 & $0.246-0.501$ & $0.259-0.487$ \\
\hline & $\mathrm{B}$ & 7 & 4 & 22 & 0.367 & $0.246-0.501$ & $0.252-0.494$ \\
\hline & $\mathrm{C}$ & 3 & 2 & 7 & 0.117 & $0.048-0.226$ & $0.052-0.219$ \\
\hline & $\mathrm{D}$ & 0 & 0 & 0 & 0 & $0.000-0.060$ & $0.000-0.058$ \\
\hline \multirow[t]{4}{*}{ NY } & A & 0 & 0 & 0 & 0 & $0.000-0.060$ & $0.000-0.057$ \\
\hline & B & 0 & 0 & 0 & 0 & $0.000-0.060$ & $0.000-0.050$ \\
\hline & $\mathrm{C}$ & 0 & 0 & 0 & 0 & $0.000-0.060$ & $0.000-0.046$ \\
\hline & $\mathrm{D}$ & 0 & 0 & 0 & 0 & $0.000-0.060$ & $0.000-0.050$ \\
\hline \multirow[t]{2}{*}{ All farms } & 16 & 17 & 7 & 93 & 0.097 & $0.0789-0.1174$ & $0.0796-0.1166$ \\
\hline & & \multicolumn{3}{|c|}{ Prevalence of farms with Salmonella } & 0.5625 & & \\
\hline
\end{tabular}

${ }^{1} \mathrm{FPC}=$ Finite population correction.

farms in our study self-reported occurrences of clinical salmonellosis before sample collection. Based upon our reported data as well as those of other researchers examining Salmonella shedding and prevalence in other regions of the United States, it appears that subclinical colonization with the diverse serotypes and serogroups of Salmonella enterica is relatively common across the US dairy industry. The specific serotype of Salmonella to be found on dairy farms is impossible to predict, and by definition, all Salmonella are pathogens of humans or animals. Therefore, steps to safeguard our food supply and consumers from Salmonella, as well as persons directly contacting animals on farms (e.g., open farm visits), need to be devised and implemented to further reduce human illnesses. The implementation of stringent biosecurity measures on dairies could help reduce transmission cycles of Salmonella within and between farms, and proper quarantine procedures used on new herd members could reduce introduction of novel Salmonella serotypes onto a farm.

\section{CONCLUSIONS}

Salmonella are important foodborne pathogenic bacteria that can be harbored subclinically in the intestinal tract of cattle. As shown in our data, Salmonella enter$i c a$ is a very diverse species that is found on many dairy operations across the United States. Dairy producers need to be aware that Salmonella can be found on their farms within apparently healthy cows, and appropriate biosecurity and pathogen-control procedures should be implemented on dairies to reduce horizontal and verti- cal transmission of Salmonella between cows and to humans via animal contact (i.e., open farm visits) and through the food chain.

\section{REFERENCES}

Difco Laboratories. 1998. Bacto Rappaport-Vassiliadis R10 Broth. Pages 427-428 in The Difco Manual. 11th ed. Difco Laboratories, Sparks, MD.

Edrington, T. S., M. E. Hurne, C. L. Schultz, T. R. Callaway, K. J. Genovese, K. M. Bischoff, J. L. McReynolds, R. C. Anderson, D. J. Nisbet, M. L. Looper, A. C. Fitzgerald, and T. S. Edrington. 2004a. Variation in the faecal shedding of Salmonella and E. coli O157:H7 in lactating dairy cattle and examination of Salmonella genotypes using pulsed-field gel electrophoresis. Lett. Appl. Microbiol. 38:366-372.

Edrington, T. S., C. L. Schultz, K. M. Bischoff, T. R. Callaway, K. J. Genovese, Y. S. Jung, J. L. McReynolds, R. C. Anderson, D. J. Nisbet, M. L. Looper, and T. S. Edrington. 2004b. Antimicrobial resistance and serotype prevalence of Salmonella isolated from dairy cattle in the southwestern United States. Microb. Drug Res. 10:51-56.

Enriquez, C., N. Nwachuku, and C. P. Gerba. 2001. Direct exposure to animal enteric pathogens. Rev. Environ. Health 16:117-131.

ERS/USDA. 2001. ERS estimates foodborne disease costs at $\$ 6.9$ billion per year. Online. Available http://www.ers.usda.gov/Emphases/SafeFood/features.htm. Accessed April 28, 2004.

Greiner, M. 1997. clusDATA. Software for prevalence estimation under cluster sampling. Institut. Parisitol. Trop. Med. Freie Universität Berlin, Berlin, Germany.

Grundmann, H., S. Hori, and G. Tanner. 2001. Determining confidence intervals when measuring genetic diversity and the discriminatory abilities of typing methods for microorganisms. J. Clin. Microbiol. 39:4190-4192.

Hedberg, C. W., J. A. Korlath, J.-Y. D’Aoust, K. E. White, W. L. Schell, M. R. Miller, D. N. Cameron, K. L. MacDonald, and M. T. Osterholm. 1992. A multistate outbreak of Salmonella javiana and Salmonella oranienburg infections due to consumption of contaminated cheese. JAMA 268:3203-3207.

Holmberg, S. D., J. G. Wells, and M. L. Cohen. 1984. Animal-to-man transmission of antimicrobial-resistant Salmonella: Investigations of U.S. outbreaks, 1971-1983. Science 225:833-835. 
Hunter, P. R., and M. A. Gaston. 1988. Numerical index of the discriminatory ability of typing systems: An application of Simpson's index of diversity. J. Clin. Microbiol. 26:2465-2466.

Huston, C. L., T. E. Wittum, B. C. Love, and J. E. Keen. 2002. Prevalence of fecal shedding of Salmonella spp. in dairy herds. JAVMA 220:645-649.

Jayarao, B. M., and D. R. Henning. 2001. Prevalence of foodborne pathogens in bulk tank milk. J. Dairy Sci. 84:2157-2162.

Mead, P. S., L. Slutsker, V. Dietz, L. F. McCraig, J. S. Bresee, C. Shapiro, P. M. Griffin, and R. V. Tauxe. 1999. Food-related illness and death in the United States. Emerging Infect. Dis. 5:607-625.

Popoff, M. Y., J. Bockemühl, and L. L. Gheesling. 2004. Supplement 2002 (no. 46) to the Kauffmann-White scheme. Res. Microbiol. 155:568-570.

Pritchard, G. C., G. A. Willshaw, J. R. Bailey, T. Carson, and T. Cheasty. 2000. Verocytotoxin-producing Escherichia coli O157 on a farm open to the public: Outbreak investigation and longitudinal bacteriological study. Vet. Rec. 147:259-264.

Roy, R., R. Higgins, M. Fortin, and S. Tardif. 2001. Salmonella Give infection in 2 dairy herds. Can. Vet. J. 42:468-470.
USDA/APHIS. 2001. Subject: Salmonella in United States feedlots. Online. Available http://www.aphis.usda.gov/vs/ceah/ncahs/ nahms/feedlot/Feedlot99/FD99salmonella.pdf. Accessed Oct. 27, 2004.

USDA/APHIS. 2003a. Subject: Salmonella and Campylobacter on U.S. Dairy Operations. Online. Available http://www.aphis.usda.gov/vs/ceah/ncahs/nahms/dairy/Dairy02/Dairy02SalCampy.pdf. Accessed Oct. 25, 2004.

USDA/APHIS. 2003b. Subject: Salmonella and Listeria in bulk tank milk on U.S. dairies. http://www.aphis.usda.gov/vs/ceah/ncahs/ nahms/dairy/Dairy02/Dairy02bulktank.pdf. Accessed Oct. 28, 2004

Warnick, L. D., K. Kanistanon, P. L. McDonough, and L. Power. 2003. Effect of previous antimicrobial treatment on fecal shedding of Salmonella enterica subsp. enterica serogroup B in New York dairy herds with recent clinical salmonellosis. Prev. Vet. Med. 56:285-297.

Wells, S. J., P. J. Fedorka-Cray, D. A. Dargatz, K. Ferris, and A. Green. 2001. Fecal shedding of Salmonella spp. by dairy cows on farm and at cull cow markets. J. Food Prot. 64:3-11. 